\title{
Towards a new WHO classification of renal cell tumor: what the clinician needs to know - a narrative review
}

\author{
Alessia Cimadamore ${ }^{1}$, Liang Cheng ${ }^{2}$, Marina Scarpelli ${ }^{1}$, Francesco Massari ${ }^{3}$, Veronica Mollica ${ }^{3}$, \\ Matteo Santoni ${ }^{4}$, Antonio Lopez-Beltran ${ }^{5}$, Rodolfo Montironi ${ }^{1}$, Holger Moch ${ }^{6}$ \\ ${ }^{1}$ Section of Pathological Anatomy, Polytechnic University of the Marche Region, School of Medicine, United Hospitals, Ancona, Italy; ${ }^{2}$ Department \\ of Pathology and Laboratory Medicine, Indiana University School of Medicine, Indianapolis, IN, USA; ${ }^{3}$ Division of Oncology, S. Orsola-Malpighi \\ Hospital, Bologna, Italy; ${ }^{4}$ Oncology Unit, Macerata Hospital, 62012 Macerata, Italy; ${ }^{5}$ Department of Surgery, Cordoba University Medical School, \\ Cordoba, Spain; ${ }^{6}$ Department of Pathology and Molecular Pathology, University and University Hospital Zurich, CH-8091 Zurich, Switzerland \\ Contributions: (I) Conception and design: A Cimadamore, R Montironi, H Moch; (II) Administrative support: R Montironi; (III) Provision of \\ study materials or patients: None; (IV) Collection and assembly of data: A Cimadamore, F Massari, V Mollica, M Santoni; (V) Data analysis and \\ interpretation: A Lopez-Beltran, L Cheng, M Scarpelli; (VI) Manuscript writing: All authors; (VII) Final approval of manuscript: All authors. \\ Correspondence to: Alessia Cimadamore. Pathological Anatomy, Polytechnic University of the Marche Region, School of Medicine, United Hospitals, \\ Via Conca 71, I-60126 Ancona, Italy. Email: alessiacimadamore@gmail.com.
}

\begin{abstract}
In 1952, renal cell carcinomas had been divided into 2 categories—clear cell or granular celldepending upon their cytoplasmic staining characteristics. In the following years, the inventory of renal epithelial tumors has expanded by the addition of tumors named by their architectural pattern (i.e., papillary RCC, tubulocystic RCC), anatomic location (i.e., collecting duct carcinoma, renal medullary carcinoma), associated diseases (i.e., acquired cystic disease-associated RCCs). With the extensive application of molecular diagnostic techniques, it becomes possible to detect genetic distinctions between various types of renal neoplasm and discover new entities, otherwise misdiagnosed or diagnosed as unclassified RCC. Some tumors such as ALK rearrangement-associated RCC, MiT family translocation renal carcinomas, SDHdeficient renal cancer or FH-deficient RCC, are defined by their molecular characteristics. The most recent World Health Organization (WHO) classification of renal neoplasms account for more than 50 entities and provisional entities. New entities might be included in the upcoming WHO classification. The aim of this review is to summarise and discuss the newly acquired data and evidence on the clinical, pathological, molecular features and on the prognosis of new RCC entities, which will hopefully increase the awareness and the acceptance of these entities among clinicians and improve prognostication for individual patients.
\end{abstract}

Keywords: Renal cell carcinoma; classification; molecular pathology; clear cell RCC; non-clear cells RCC; emerging entities; Von Hippel-Lindau gene (VHL); fumarate hydratase (FH); succinate dehydrogenase (SDH); anaplastic lymphoma kinase (ALK)

Submitted Aug 06, 2020. Accepted for publication Oct 15, 2020.

doi: $10.21037 / \mathrm{tau}-20-1150$

View this article at: http://dx.doi.org/10.21037/tau-20-1150

\section{Introduction}

In the last 70 years, from 1952 to 2020, the clinical spectrum of renal cell carcinomas (RCC) has expanded by the increased recognition of new entities and the refinements of existing categories $(1,2)$. The classification system has grown along with electron microscopy, immunohistochemistry, cytogenetics, and molecular diagnostic techniques. Some tumors such as ALK rearrangement-associated RCC, MiT family translocation renal carcinomas, SDH-deficient renal cancer or FH-deficient RCC, are defined by their molecular characteristics (3). The most recent World Health Organization (WHO) classification of renal neoplasms 
account for more than 50 entities and provisional entities $(4,5)$. New entities might be included in the upcoming WHO classification.

However, besides an increasing understanding of the tumor histologies and biological behaviour, only few tumor entities have a specific treatment and ongoing clinical trial are still adopting the old classification of clear cells RCC (ccRCC) and non-clear cells RCC (nccRCC) as selection criteria (6).

This review will summarise and discuss the newly acquired data and evidence on the clinical, pathological, molecular features of the new entities included in the WHO 2016 classification and of the emerging/provision entities, which will hopefully increase the awareness and their acceptance among clinicians and improve prognostication for individual patients. A PubMed search using the keywords "renal cell carcinoma", "emerging entities", "provisional entities", "molecular classification", from 2005 and June 2020 was performed.

It is beyond the scope of this review to describe in detail the various diagnostic pathological features and immunohistochemical antibody expression of these tumors. Detailed information about each entities are available in all the cited papers. We present the following article in accordance with the NARRATIVE REVIEW reporting checklist (available at http://dx.doi.org/10.21037/tau-201150).

\section{Narrative review}

\section{New renal tumor entities}

Newly recognized epithelial renal tumours in the 2016 WHO classification are HLRCC associated RCC, SDHdeficient RCC, tubulocystic RCC, acquired cystic RCC, and clear cell papillary RCC (4).

\section{Hereditary leiomyomatosis and renal cell carcinoma (HLRCC) syndrome-associated renal cell carcinoma/ FH-deficient RCC}

HLRCC associated RCC are highly aggressive tumors that early metastasize, with frequent spread to regional lymph nodes, even if of small size $(7,8)$. These rare tumors occur in people affected by an autosomal dominant tumor syndrome associated with germline mutations in the fumarate hydratase $(\mathrm{FH})$ gene at chromosome $1 \mathrm{q} 42$. Patients with HLRCC syndrome usually present cutaneous leiomyomas and in female uterine leiomyoma and less frequently leiomyosarcomas $(9,10)$. Thirty percent of the patients can also develop RCC, characterized by type 2 papillary growth pattern and large nucleus with prominent orangiophilic or eosinophilic nucleolus, surrounded by a clear halo, resembling a viral inclusion which is the hallmark of these neoplasms. Same cytological features have been also described in uterine leiomyoma of these syndromic patients (11). An accurate diagnosis of these tumors is of primary importance for the correct management of the patients and their families. The germline mutations of the $\mathrm{FH}$ gene is the specific genetic alteration for these tumors and is detectable by IHC for FH antibody (loss of expression) or for S-2(2-succino)-cysteine (2SC) (strong and diffuse nuclear and cytoplasmic stain) or by molecular testing (12). In the setting of uncertain clinical and family history and unknown genetic status, is recommended to use "FH-deficient RCC" for tumors that show IHC-negative staining for $\mathrm{FH}$ and strong $2 \mathrm{SC}$ reactivity (12) (Figure $1 \mathrm{~A}$ and $1 B$ ). Report of two syndromic cases treated in first-line with bevacizumab/erlotinib showed significant and long lasting response (13).

\section{Succinate dehydrogenase deficient neoplasia}

These category of tumors account for about $0.05 \%$ to $0.2 \%$ of renal neoplasms and are defined by the doublehit inactivation of one of the SDH genes (SDHA, SDHB, SDHC, SDHD, and SDHAF2), an event that occurs only rarely in the absence of a germline mutation $(14,15)$. Patients with germline mutation can also develop pheochromocytomas/paragangliomas, gastrointestinal stromal tumors, and pituitary adenomas. Presence of these rare type of tumors in the same patient/family should raise the suspicion of a germline mutation and encourage genetic counselling. The majority of the cases have loss of SDHB gene identifiable by loss of immunohistochemical stain. The median age at presentation is around 40 years with a wide range (14-76 years), they are typically solitary masses, multifocal and bilateral in 30\% of patients. Low grade SDH-deficient RCC and without coagulative necrosis are associated with good outcome, while presence of necrosis, high grade and sarcomatoid features can present metastatic spread in $70 \%$ of the cases (16-18) (Figure 1C).

\section{Tubulocystic RCC}

Tubulocystic renal cell carcinoma (TCC RCC) was first comprehensively described by George Farrow and then by Amin et al. under the spectrum of collecting duct carcinoma. Because these tumors were entirely composed of tubules and 

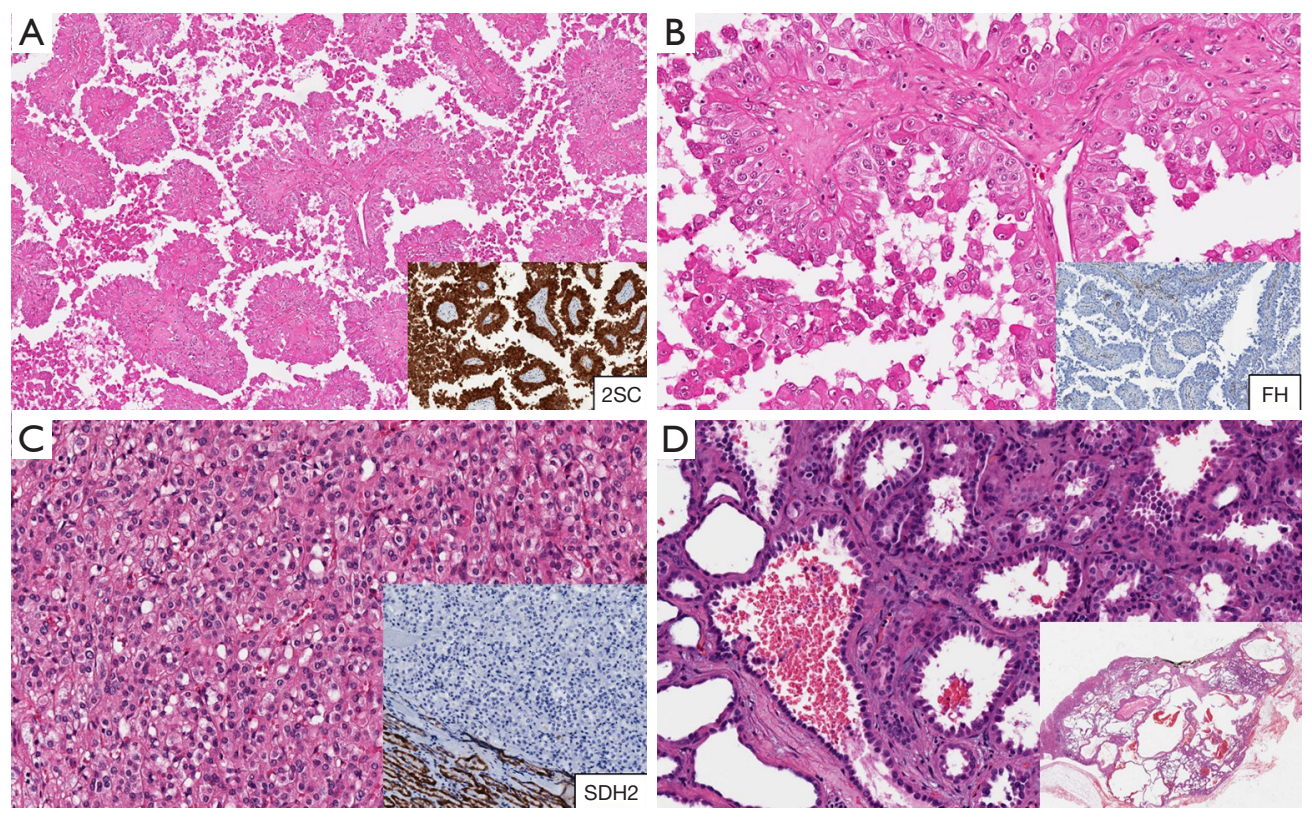

Figure 1 FH-Deficient RCC, at low (2x) (A) and high magnification (20x) (B), with strong and diffuse positivity for 2SC and loss of FH expression (inserts); Succinate Dehydrogenase Deficient Neoplasia (10×) (C) with loss of SDH2 expression (insert); Tubulo-cystic RCC (10×) (D), at low magnification (insert).

duct-like structures, it was initially call low-grade collecting duct carcinoma for its appearance and its significantly different behavior compared to the classical highly aggressive collecting duct carcinomas. Genetic alteration of TCC RCC are distinct from those of ccRCC, pRCC, ChRCC and also from collecting duct carcinomas. More than 80 cases have been reported so far with strong prevalence in males (male/female ratio of 7:1) and higher incidence in the fifth and sixth decade. Most of the tumors are cystic and in pT1 stage and behave in an indolent fashion. Only rare cases presented metastasis to the pelvic lymph nodes, bone, liver and peritoneum (19-23) (Figure 1D).

\section{Clear cell papillary RCC}

Clear cell Papillary RCC (CCPRCC) is thought to have a prevalence rate of approximately $1-4 \%$ and that about $6 \%$ of low-grade ccRCC are, in fact, CCPRCC, making this entity the fourth most common RCC subtype. The characteristic immunoprofile with diffuse cytokeratin 7 staining, GATA3 positivity, "cup-shaped" carbonic anhydrase IX staining distribution, and negative results for AMACR and CD10, along with the absence of VHL alterations in almost all tumor, distinguish this entity from ccRCC and papillary RCC. When the immunohistochemistry shows an imperfect staining pattern, current recommendations advise to classify such tumors as ccRCC and to refers to genetic analysis for VHL mutation or chromosome $3 p$ loss (24-26) (Figure 2A,B,C).

\section{Acquired cystic disease-associated renal cell carcinoma (ACD-RCC)}

Patients with acquired cystic disease (ACD) of the kidney have a risk of develop a renal tumors about 100 times higher than the general population, a risk that increases with the duration of the dialysis. ACD-RCC is specific for the cystic disease condition and occurs only in end-stage renal disease patients, but patients with ACD can develop also other RCC histotypes. The vast majority of ACD-RCC present intratumoral calcium oxalate deposition in the luminal structures and in the stroma. These tumors have been usually detected at an early stage, thus the clinical course is usually indolent. Few cases with sarcomatoid component have been reported and were associated with poor outcome (27-30) (Figure 2D).

\section{Emerging or provisional renal tumour entities}

The 2016 WHO classification includes some rare entities, not yet well characterized in terms of morphology, immunohistochemical stain and genetic features, therefore 

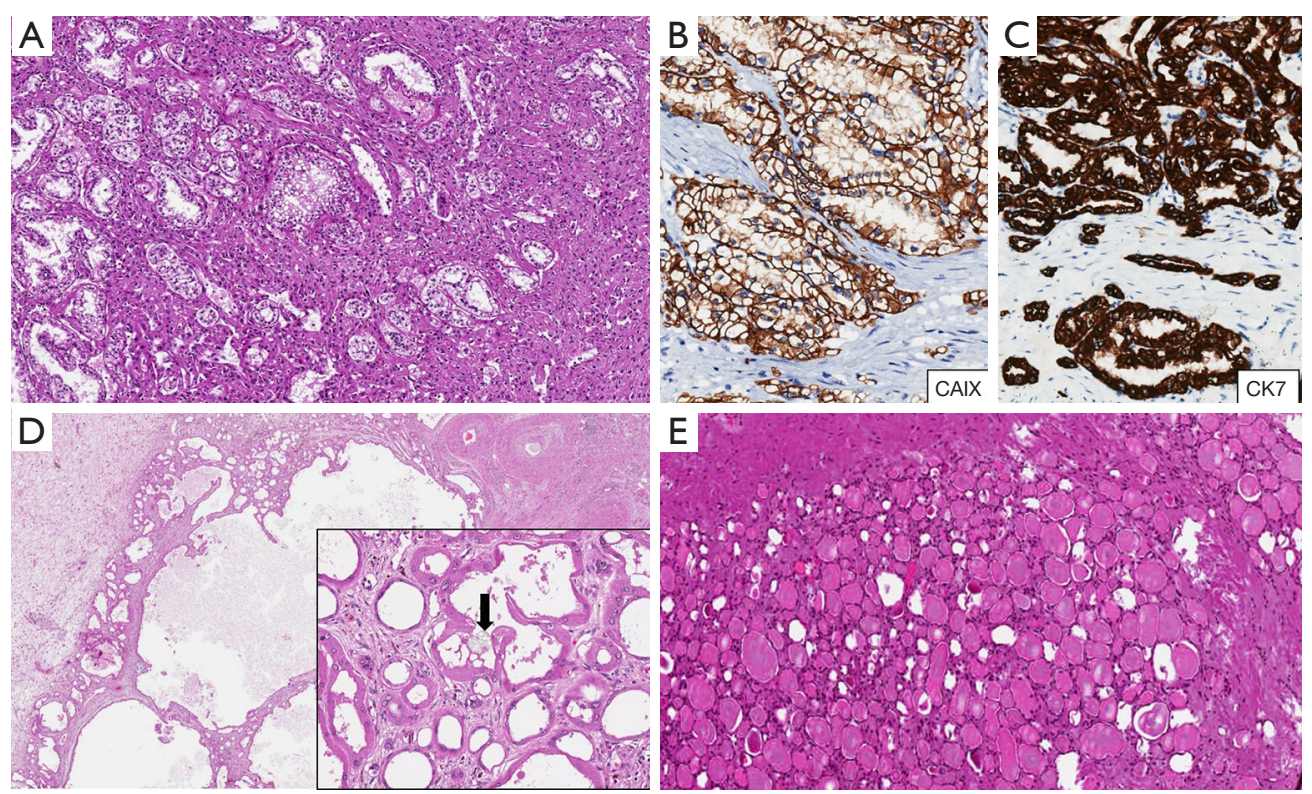

Figure 2 Clear cell papillary RCC. Clear cells of low nuclear grade, variable papillary, tubular-acinar and cystic architecture in a fibroleiomyomatous stroma (10×) (A), “cup-shaped” carbonic anhydrase IX staining distribution (20x) (B), strong and diffuse CK7 positivity $(20 \times)(C)$. Acquired cystic disease-associated renal cell carcinoma (4x) (D), note the oxalate crystals (arrow) at higher magnification (insert); Thyroid like follicular RCC (4x) (E).

placed under the category "emerging/provisional tumors". These entities are thyroid-like follicular RCC, RCCs associated with ALK gene rearrangement, Renal cell carcinoma with (angio) leiomyomatous stroma and TCEB1 mutated RCC. RCC in neuroblastoma survivors was removed from $2016 \mathrm{WHO}$ classification and its now considered an emerging entity.

\section{Thyroid like follicular RCC}

To data, less than 40 cases of Thyroid like follicular RCC have been reported, 27 in female and 12 in male patients and a median age of 35 years. These curious entities are characterized by structures resembling thyroid follicles with accumulation of inspissated colloid-like material that closely mimic a well-differentiated thyroid follicular neoplasms. The main differential diagnosis are a chronic pyelonephritis or a metastatic thyroid carcinoma. Thyroid like follicular RCC are in most of the cases indolent neoplasms. Few cases reported spread in hilar lymph nodes and distant metastasis, but all the patients survived after surgical resection (31-34) (Figure 2E).

\section{Anaplastic lymphoma kinase (ALK) Rearrangement- Associated RCC (ALK-RCC)}

ALK-RCC has been described in 2011 and less than 30 cases have been reported so far (35-43).

They are usually solitary tumor, not associated with any syndrome, with a slight prevalence in males and reported in a wide age range, including adolescents. Thirty $\%$ of the cases demonstrated malignant behavior with metastasis and death. Variable and multiple morphologies can be seen in this type of tumor and the definitive diagnosis can only be done by performing IHC for ALK antibody and FISH analysis for ALK rearrangement (44) (Figure 3A,B). Multiple ALK fusion gene partners have been identified. Mucinous background, intracytoplasmic mucin and myxoid changes have been reported in a subsets of cases and can be a helpful clue to recognize these rare tumor eligible for a potential targetable therapy. "ALK IHC screening for unclassifiable RCCs with heterogeneous features" has been proposed by Kuroda and colleagues (43).

Target therapy against ALK activation (i.e., ALK inhibitors alectinib and crizotinib) have been developed for ALK rearranged tumors and have proven efficacy and tolerability. Short term clinical and radiographic response to alectinib has been recently reported in 3 patients with metastatic EML4-ALK rearranged tumors (45). In children and adolescents ALK-RCC resembles renal medullary carcinoma and collecting duct carcinoma, are frequently 

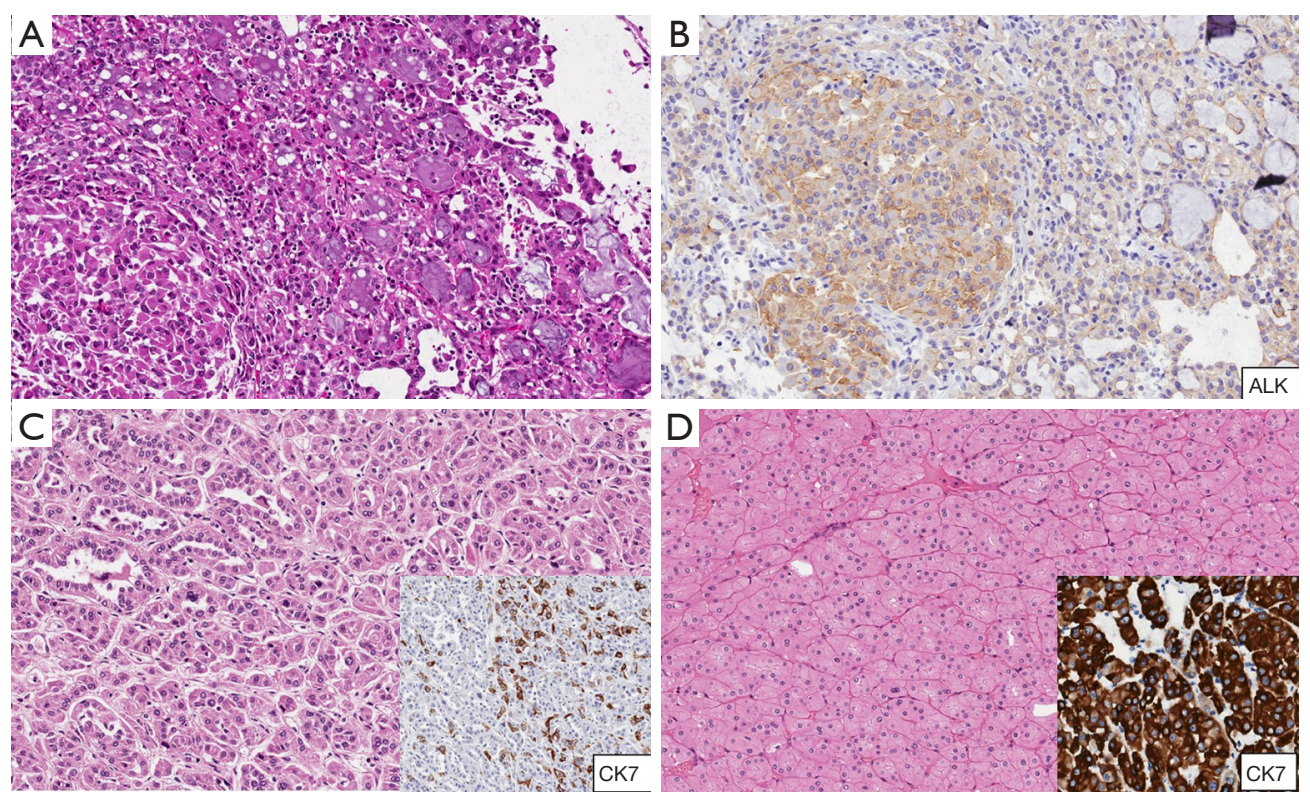

Figure 3 ALK Rearrangement-associated RCC (A, 10x) with mucinous background, ALK-IHC membrane expression (B, 10x); HOT (C, 10x) and LOT (D, 10x), with scant and diffuse CK7 expression, respectively (inserts, 20×).

located in the medulla or renal pelvis and harbor VCLALK and TPM3-ALK fusion. Until recently, VCLALK rearrangements has been reported only in pediatric patients of African American origin with the sickle-cell trait. Some cases in adult patients have been described as metanephric adenoma, mucinous tubular and spindle cell carcinoma, MiTF RCC (due to the positivity for TFE3 by IHC without FISH confirmed rearrangement for Xp11.2 translocation) (46,47).

The differential diagnosis in these cases is of great importance due to the differences in prognosis compared to a benign and indolent entities and to the implication in therapeutic choice for ALK rearranged tumors.

\section{Renal cell carcinoma with (angio) leiomyomatous stroma (RCCLMS)}

Multiple names have been used to describe this rare entity: mixed renal tumour with carcinomatous and fibroleiomyomatous components, RCC associated with prominent angioleiomyoma-like proliferation, clear cell RCC with smooth muscle stroma, RCC with clear cells, smooth muscle stroma and negativity for $3 p$ deletion, RCC with leiomyomatous stroma, and RCC with angioleiomyomatous-like stroma. These rare tumors are constituted by two admixed components, epithelial—usually nest/tubules/papillary structure of clear cell, with low grade nuclei-and stromal-non-neoplastic leiomyomatous or fibroleiomyomatous (48-52).

The presence of a prominent leiomyomatous stroma is not a feature of a specific entity, but can be seen in otherwise typical ccRCC and even in papillary RCC.

According to recent publication by Shah and colleagues, the morphology, immunohistochemical features, and molecular alterations of RCCLMS distinguish this entity from CCRCC and CCPRCC. Of the 18 sporadic RCCLMS they included in their analysis, 4 harbour TSC1, 4 TSC2, 6 MTOR, and/or 2 TCEB1 mutations and all have an intact VHL gene. Their findings support the suggestion that these tumors represent the sporadic counterpart to morphologically identical tumors occurring in TSC patients (53).

\section{TCEB1 Renal cell carcinoma}

A small fraction of wt-VHL RCC are characterized by inactivation of the TCEB1 gene that encodes for a protein part of the E3 ubiquitin ligase complex. Inactivation of TCEB1 increases HIF stabilisation via the same mechanism as VHL inactivation. These tumors are often accompanied by loss of chromosome 8 (often in the form of monosomy). These new entity resembles ccRCC, express CAIX as well, and usually present thick fibromuscular bands transecting the tumor and clear cell cytology with voluminous 
cytoplasm. Although initial data on this subset suggested that they are nonaggressive, recent reports of aggressive behaviour have been published (53-56).

\section{New aspects in classic tumor entities}

\section{Clear cell RCC: VHL alterated and VHL wild type entities}

Clear cell RCC is the most prevalent histotype among RCC, accounting for about $70 \%$ of all cases, historically defined by clear cell cytoplasm and a characteristic network of small, thin walled, vasculature. The majority of ccRCC are characterized by the biallelic loss of the VHL tumor suppressor gene in the short arm of chromosome 3 that can occurs via mutations, copy deletion and promoter hypermethylation. Patients affected by von HippelLindau syndrome inherited a single inactivated copy of the VHL gene and usually develop other tumor types such as hemangioblastomas, pheochromocytoma, pancreatic cysts, endolymphatic sac tumor, and cystadenomas of the epididymis (men) or broad ligament of the uterus (women) (57-59). In the last decades, some tumor entities have been described with clear cell cytoplasm and showing morphological overlap with clear cell papillary RCC, RCC with (angio) leiomyomatous stroma, translocation carcinomas, and TCEB1 renal cancer. However, these tumors do not share the same genetic aberrations of ccRCC and should be distinguished from the classical VHL-mutated ccRCC (56). A correct classification of these tumors is relevant from a clinical prognostic point of view since these tumors (i.e., CCPRCC, RCCLMS, MiT family translocation RCC) are mostly indolent while others such as ccRCC VHL-wild type have been associated with a higher aggressiveness, sarcomatoid features and rapid progression (60-62).

\section{Papillary renal cell carcinoma: more than just type 1 and type 2}

Papillary RCC has seen the most marked changes during the last decade. It is a heterogeneous category that comprehends indolent entities and aggressive high lethal tumors. The molecular characterization published in 2016 distinguished two categories: type 1, the most uniform subgroup, typically associated with MET alterations, and type 2 tumors characterized by different genetic alterations (such as CDKN2A silencing, SETD2 mutations, TFE3 fusions, and increased expression of the NRF2-antioxidant response element pathway) and composed by multiple specific neoplasms rather than a single specific entity. A CpG island methylator phenotype (CIMP) has been reported in a $\mathrm{FH}$ deficient pRCC (often associated with the hereditary leiomyomatosis and renal cell carcinoma syndrome [HLRCC]) (63). Type 2 papillary RCC had worse outcomes compared to type 1 , and usually have higher nuclear grade, higher stage and tumor size with a $6 \%$ of lymph nodes metastasis (64).

\section{Chromophobe RCC: How to distinguish the good one from the bad one}

Chromophobe RCC (ChRCC) accounts for approximately $5-7 \%$ of all adult renal tumors and it is usually composed of epithelial cells, polygonal pale cells, and eosinophilic cells, with accentuated cellular membranes, raisin-like nuclei and perinuclear halos. Due to constitutive atypia of the nuclei, the presence of binucleation, and the nucleolar prominence, the World Health Organization/International Society of Urologic Pathologists (WHO/ISUP) nucleolar system cannot be applied in ChRCC (4). However, a histological grading system with a prognostic validation is greatly needed. Its course is generally indolent but a minority of cases develop metastases and respond poorly to the currently available therapy. Grading system proposal are based on the presence of three parameters: sarcomatoid differentiation, histological coagulative tumor necrosis, and presence of mitosis (65-68).

Using such a grading system, a statistically significant difference was reported in overall survival in univariate analysis. However, low to medium concordance was reported in the identification of mitosis. Therefore, a twotiered tumor grading system based only on presence of sarcomatoid differentiation and necrosis was proposed by Ohashi et al. This system showed high accuracy in prediction of time to progression, overall survival and high interobserver reproducibility $(67,68)$.

From a molecular prospective, ChRCC is characterized by multiple chromosome losses (chromosome Y, 1,2,6,10,13,17.21), a reduced expression of "Copynumber alterations Yielding Cancer Liabilities Owing to Partial losS" (CYCLOPS) genes and TP53 and PTEN mutations (69). Patients with metastatic disease has an increased tumor mutation rates in these two genes and an imbalanced chromosome duplication (70). In difficult cases, chromosomal copy number alterations can be used for the differential diagnosis between the eosinophilic variant of 
ChRCC and oncocytoma. Losses of chromosome 1 and $\mathrm{Y}$ has been found also in benign oncocytoma while losses of chromosomes 2, 6, 10, or 17 are not and can be used to exclude the benign entity (71-74). Recently the group of Ohashi et al. discovered that a reduced CDKN1A mRNA expression levels and CDKN1A immuno-negativity were associated with poor outcome in ChRCC (75).

In case of hybrid tumors and in patients with multiple oncocytic tumors, the analysis of FLCN gene (folliculin) can be performed to support the diagnosis of Birt-HoggDubè syndrome (44).

\section{High-grade oncocytic tumor (HOT) and Low-grade oncocytic tumor (LOT)}

In the spectrum of oncocytic tumors difficult to classify, two distinct entities have been recently proposed: High-grade oncocytic tumor (HOT) and Low-grade oncocytic tumor (LOT). HOT and LOT are eosinophilic tumors that do not fit in any of the currently recognized tumor categories, in particular oncocytic tumors such as oncocytoma, ChRCC, hybrid oncocytic tumors either sporadic or syndromic. Twenty-two HOT cases have been published since now, one sporadic and just one in a patient with TSC (76-80). The cases reported are more often females with a median age of 55 years, all with indolent behavior. The immunoprofile (CD117+, CK7 focal) and the electronic microscopy appearance mimics the one of the oncocytoma, however the high-grade morphology, with enlarged nucleoli that resemble viral inclusions, and the cytoplasmic vacuoles are not usually encountered in a classical oncocytoma. FLCN mutation detection can be of help in distinguishing a hybrid tumor from a HOT.

On the other hand, LOT presents diffuse positivity for CK7, invariably CD117-negative and has been described as eosinophilic ChRCC with absence of any consistent chromosomal losses or gains. The cells have a low-grade appearance with often delicate perinuclear clearing. The 28 cases published consisted in single small tumors with indolent course, slightly prevalent in females with a median age of 66 years (81-83) (Figure $3 C$ and $3 D$ ).

\section{MiT family translocation RCC (tRCC)}

tRCC accounts for $1-4 \%$ of RCC in adult and around $50 \%$ of pediatric RCC. They are characterised by gene fusions involving TFE3 or TFEB, 2 members of the MiT family of transcription factors. The most common chromosomal translocations are $\mathrm{Xp} 11$, involving the oncogenic activation of the TFE 3 transcription factor (Figure 4A) and, less frequently, 6;11 (p21;q12), involving TFEB. Xp11 translocation RCCs typically have a papillary/ nested growth pattern and are composed of clear cells with frequent associated psammomatous calcifications whereas 6;11 translocations RCC have usually nested architecture and are constituted of a biphasic population of larger and smaller epithelioid cells clustered around hyaline basement membrane material. $\mathrm{t}(6 ; 11)$ RCCs are usually indolent (84-86). Among this category, Gupta et al. identified 25 cases of TFEB-amplified RCC associated with amplifications of VEGFA (which exists in 6p21, same with TFEB) that showed oncocytic and tubulopapillary features with highgrade nuclei, and their clinical courses were aggressive with metastasis and death from RCC in $46 \%$ of cases (87). To date, 54 cases of TFEB-amplified tumors have been reported, a small percentage of which harboring both TFEB translocation and amplification. Overall, TFEB amplified tumors shows high nuclear grade, pseudopapillary/nested/ tubular structure and an aggressive clinical behaviour. Notably, $50 \%$ of the published cases were negative for TFEB expression by immunohistochemistry (88).

\section{Mucinous tubular spindle cell carcinoma (MTSCC)}

Already included as in the 2004 WHO under the name mucinous tubular and spindle cell carcinoma, these tumors often exhibits overlapping histologic and immunophenotypic feature with PRCC type 1. While the classic MTSCC harbors multiple chromosomal losses without the trisomy of chr 7 and 17, the overlapping cases show a chromosomal alteration pattern similar to solid variant of PRCC type 1 cases, including gains of chromosomes 7 and $17(89,90)$. To distinguish these tumors with overlapping histology has been recently proposed a new cancer-specific and lineage-specific biomarkers VSTM2A specifically overexpressed in MTSCC (91).

MTSCC generally presents at low pathologic stage at the time of excision, and the majority of the MTSCC with classic histology behave in an indolent fashion. However, presence of high nuclear grade and sarcomatoid features have been associated with lethal outcomes $(92,93)$ (Figure 4B).

\section{Renal medullary carcinoma and Collecting duct carcinoma}

Renal medullary carcinomas (RMCs) and collecting duct 

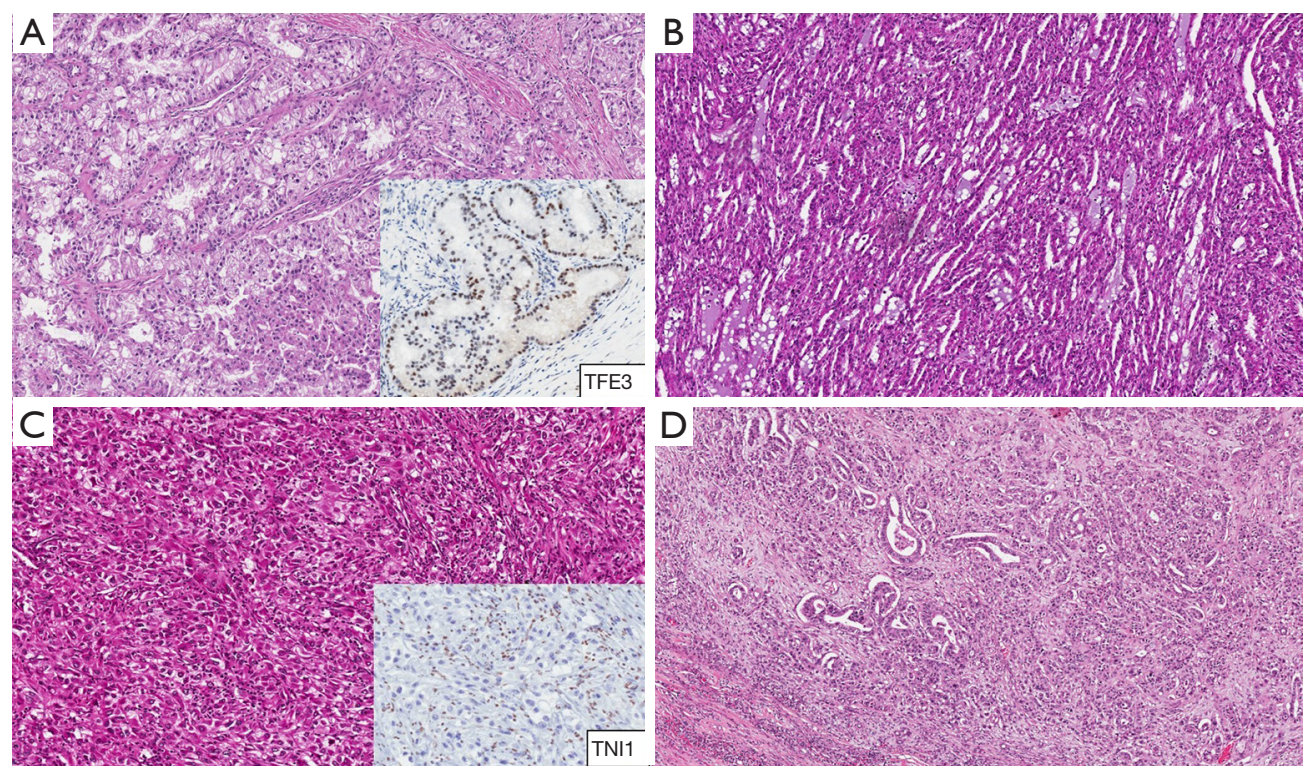

Figure 4 Xp11 translocation RCCs (A, 10×), TFE3 IHC staining (insert); Mucinous tubular spindle cells carcinoma (B, 4×); Renal medullary carcinoma (C, 10×) with loss of SMARCB1 (INI1) expression by IHC (insert); Collecting duct carcinoma (D, 4x).

carcinomas (CDCs) are well-know, rare high grade renal tumors, usually sited in the renal medullary region. They often present at high-stage and are associated with a dismal prognosis. On the basis of the recent modified diagnostic approach and new entities, $25 \%$ of tumors previously diagnosed as CDC were reclassified as FH-deficient RCC. Exclusion of metastatic adenocarcinoma, urothelial carcinoma of the pelvi-calyceal system, renal medullary carcinoma, and FH-deficient RCC are required to render a diagnosis of CDC. RMC typically in children or young adults of African, South American and Mediterranean origin with sickle cell trait or disease. The diagnostic criteria for RMC are stricter and include the presence of hemoglobinopathy (sickle cell trait or related hemoglobinopathies and/or finding sickleshaped erythrocytes (drepanocytes) in the histologic samples) and complete loss of SMARCB1 (INI1) expression by IHC (94-97) (Figure 4C and 4D).

\section{Discussion: recommendations for the next $W H O$ classification}

\section{Eosinophilic solid and cystic RCC (ESC RCC)}

ESC RCC is an emerging renal tumor entity not yet part of the 2016 WHO classification of genitourinary tumors $(4,98,99)$. It was recently described as a sporadic neoplasms occurring in young women, usually solitary, small and with indolent behavior. Subsequent studies have reported identical tumor also in males and multifocal, in a minority of cases. Metastases have been reported in four cases so far. Ten percent of the patients with tuberous sclerosis-complex (TSC) can present this type of tumor, firstly described with "granular eosinophilic-macrocystic morphology" by Guo et al. (100-102). In a case series of unclassified eosinophils tumor in patients of 35 years of age or younger, $30 \%$ of the cases were classified as ESC-RCC (17). Solid and cystic architecture, voluminous eosinophilic cytoplasm, granular cytoplasmic stippling, CK20 positivity either diffuse or focal are the typical features of these tumors, although CK 20 negative cases (10-15\%) have been reported (Figure $5 A$ and $5 B)$. Next generation sequencing analysis and karyotype profiling evidenced that ESC-RCC are characterized by somatic tuberous sclerosis gene mutations (TSC1 and TSC2) in the great majority of cases and recurring chromosomal copy number gains and losses. Since many of the genes involved in these alterations are part of the regulation of MTOR signaling pathway, therapies targeting the mTOR pathway in these RCC can be considered $(103,104)$.

\section{Biphasic squamoid papillary RCC}

Initially reported in 2012 by Petersson et al. and later in a 

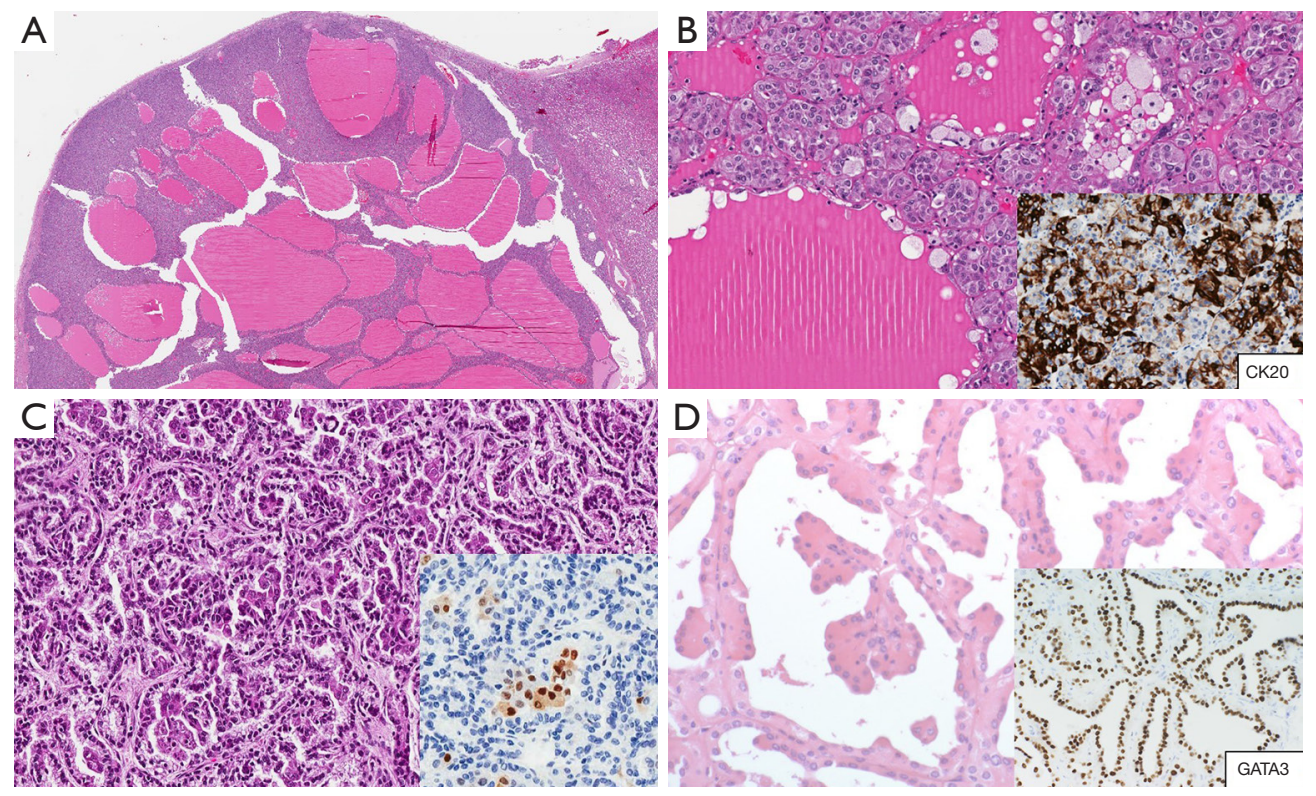

Figure 5 Eosinophilic solid and cystic RCC at low magnification (A, 2×) and high magnification (B, 20x), CK20 expression (insert); Biphasic squamoid papillary RCC (C, 10x), BCL1 IHC stained the squamoid cells (insert); Papillary renal neoplasm with reverse polarity (D, 40×), positive nuclear staining with GATA 3 (insert).

larger series by Hes et al. this new entity may represent a distinct subtype of papillary RCC type 1, on the basis of the morphological, immunohistochemical and molecular similarities $(105,106)$.

The name is given by the presence of two cell populations: one constituted by larger eosinophilic cells with abundant cytoplasm and higher-grade nuclei designated as 'squamoid' (squamous cell-like), organized in glomeruloid or micronodular formations resembling alveolar structures; and a population of smaller cells with amphophilic or clear and scant cytoplasm, admixed with the larger cells. These tumors can be multifocal, bilateral, associated with other tumors such as multiple papillary adenomas, papillary RCC, clear cell RCC, and low-grade urothelial carcinoma, and can express malignant behaviour with metastasis, recurrence, or death due to the disease in $15 \%$ patients (107-110) (Figure 5C).

\section{Papillary renal neoplasm with reverse polarity (PRNRP)}

A distinct subset of papillary renal tumors with reverse polarity was recently described by Al-Obaidy and colleagues (111). These tumors are characterized by low-grade nuclear features, inverted nuclear location, eosinophilic cytoplasm, branching papillae with thin fibrovascular cores and indolent clinical behavior. They are characteristically positive for GATA3 and L1CAM and the great majority of them $[93 \%$ in the series of Kim et al. (112)] harbors recurrent mutation of KRAS, whereas no KRAS mutation have been reported in any of papillary type 1 and type 2 cohort used as controls $(112,113)$. After a median follow-up of 54 months, all patients with PRNRP were alive with no evidence of disease (Figure 5D) (Table 1).

\section{Conclusions}

In addition to common histological subtypes known for decades, many entities with distinct morphological and molecular features are under active investigation and may be included in future classifications. The more accurate identification of these tumors with the help of ancillary techniques and genetic analysis will improve patient's stratification and therapy and may have an impact on their families in the specific case of a genetic syndrome-associated RCC. 
Table 1 Renal cell tumors and new described entities grouped according to their cellular features/architectural pattern, anatomic location, associated diseases, and genetic alterations

\begin{tabular}{|c|c|c|c|}
\hline Cellular features and/or Architectural pattern & Anatomic location & Associated diseases & Genetic alterations \\
\hline - Clear Cell RCC & $\begin{array}{l}\text { - Renal medullary } \\
\text { carcinomas }\end{array}$ & $\begin{array}{l}\text { - Acquired cystic } \\
\text { disease-associated } \\
\text { RCC }\end{array}$ & - TCEB1 RCC \\
\hline - Papillary RCC & - Collecting duct & - $\mathrm{RCC}$ in neuroblastoma & - MiT family translocation RCC \\
\hline - Chromophobe RCC & carcinomas & survivors & - $\mathrm{FH}$ deficient $\mathrm{RCC}$ \\
\hline - Clear cell papillary RCC & & & - SDH-deficient neoplasia \\
\hline - Biphasic squamoid papillary RCC & & & \\
\hline - Mucinous tubular spindle cell carcinoma & & & \\
\hline - HOT/LOT & & & \\
\hline - Thyroid like follicular RCC & & & \\
\hline - Papillary renal neoplasm with reverse polarity & & & \\
\hline
\end{tabular}

\section{Acknowledgments}

Funding: None.

\section{Footnote}

Provenance and Peer Review: This article was commissioned by the editorial office, Translational Andrology and Urology for the series "Update on Molecular Classification and Individualized Treatments of Genitourinary Tumors". The article has undergone external peer review.

Reporting Checklist: The authors have completed the NARRATIVE REVIEW reporting checklist. Available at http://dx.doi.org/10.21037/tau-20-1150

Conflicts of Interest: All authors have completed the ICMJE uniform disclosure form (available at http://dx.doi. org/10.21037/tau-20-1150). The series "Update on Molecular Classification and Individualized Treatments of Genitourinary Tumors" was commissioned by the editorial office without any funding or sponsorship. AC, LC, MS, ALB and RM served as the unpaid Guest Editors of the series. LC serves as an unpaid editorial board member of Translational Andrology and Urology from Dec 2018 to Nov
2022. The authors have no other conflicts of interest to declare.

Ethical Statement: the authors are accountable for all aspects of the work in ensuring that questions related to the accuracy or integrity of any part of the work are appropriately investigated and resolved.

Open Access Statement: This is an Open Access article distributed in accordance with the Creative Commons Attribution-NonCommercial-NoDerivs 4.0 International License (CC BY-NC-ND 4.0), which permits the noncommercial replication and distribution of the article with the strict proviso that no changes or edits are made and the original work is properly cited (including links to both the formal publication through the relevant DOI and the license). See: https://creativecommons.org/licenses/by-nc-nd/4.0/.

\section{References}

1. MacLennan GT, Cheng L. Five decades of urologic pathology: the accelerating expansion of knowledge in renal cell neoplasia. Hum Pathol 2020;95:24-45.

2. Herbut PA. Urologic Pathology. Philadelphia, PA: Lea and Febiger; 1952. 
3. Cheng L, Zhang S, MacLennan GT, et al. Molecular and cytogenetic insights into the pathogenesis, classification, differential diagnosis, and prognosis of renal epithelial neoplasms. Hum Pathol 2009;40:10-29.

4. Moch H, Humphrey PA, Ulbright TM, Reuter VE. WHO classification of tumors of the urinary system and male genital organs. Lyon, France: IARC; 2016.

5. Moch H, Cubilla AL, Humphrey PA, et al. The 2016 WHO Classification of Tumours of the Urinary System and Male Genital Organs-Part A: Renal, Penile, and Testicular Tumours. Eur Urol 2016;70:93-105.

6. Motzer RJ, Jonasch E, Michaelson MD, et al. NCCN Guidelines Insights: Kidney Cancer, Version 2.2020. J Natl Compr Canc Netw 2019;17:1278-85.

7. Miettinen M, Felisiak-Golabek A, Wasag B, et al. Fumarase-deficient uterine leiomyomas: An immunohistochemical, molecular genetic, and clinicopathologic study of 86 cases. Am J Surg Pathol 2016;40:1661-9.

8. Merino MJ, Torres-Cabala C, Pinto P, et al. The morphologic spectrum of kidney tumors in hereditary leiomyomatosis and renal cell carcinoma (HLRCC) syndrome. Am J Surg Pathol 2007;31:1578-85.

9. Kiuru M, Launonen V, Hietala M, et al. Familial cutaneous leiomyomatosis is a two-hit condition associated with renal cell cancer of characteristic histopathology. Am J Pathol 2001;159:825-9.

10. Launonen V, Vierimaa O, Kiuru M, et al. Inherited susceptibility to uterine leiomyomas and renal cell cancer. Proc Natl Acad Sci U S A 2001;98:3387-92.

11. Harrison WJ, Andrici J, Maclean F, et al. Fumarate hydratase-deficient uterine leiomyomas occur in both the syndromic and sporadic settings. Am J Surg Pathol 2016;40:599-607.

12. Trpkov K, Hes O, Agaimy A, et al. Fumarate hydratasedeficient renal cell carcinoma is strongly correlated with fumarate hydratase mutation and hereditary leiomyomatosis and renal cell carcinoma syndrome. Am J Surg Pathol 2016;40:865-75.

13. Wyvekens N, Valtcheva N, Mischo A, et al. Novel morphological and genetic features of fumarate hydratase deficient renal cell carcinoma in HLRCC syndrome patients with a tailored therapeutic approach. Genes Chromosomes Cancer 2020;59:611-9.

14. Gill AJ, Pachter NS, Clarkson A, et al. Renal tumors and hereditary pheochromocytoma-paraganglioma syndrome type 4. N Engl J Med 2011;364:885-6.

15. Gill AJ, Pachter NS, Chou A, et al. Renal tumors associated with germline SDHB mutation show distinctive morphology. Am J Surg Pathol 2011;35:1578-85.

16. Williamson SR, Eble JN, Amin MB, et al. Succinate dehydrogenase-deficient renal cell carcinoma: Detailed characterization of 11 tumors defining a unique subtype of renal cell carcinoma. Mod Pathol 2015;28:80-94.

17. Li Y, Reuter VE, Matoso A, Netto GJ, Epstein JI, Argani P. Re-evaluation of 33 'unclassified' eosinophilic renal cell carcinomas in young patients. Histopathology 2018;72:588-600.

18. McEvoy CR, Koe L, Choong DY, et al. SDH-deficient renal cell carcinoma associated with biallelic mutation in succinate dehydrogenase A: comprehensive genetic profiling and its relation to therapy response. NPJ Precis Oncol 2018;2:9.

19. Yang XJ, Zhou M, Hes O, et al. Tubulocystic carcinoma of the kidney: Clinicopathologic and molecular characterization. Am J Surg Pathol 2008;32:177-87.

20. Osunkoya AO, Young AN, Wang W, et al. Comparison of gene expression profiles in tubulocystic carcinoma and collecting duct carcinoma of the kidney. Am J Surg Pathol 2009;33:1103-6.

21. Amin MB, MacLennan GT, Gupta R, et al. Tubulocystic carcinoma of the kidney: Clinicopathologic analysis of 31 cases of a distinctive rare subtype of renal cell carcinoma. Am J Surg Pathol 2009;33:384-92.

22. MacLennan GT, Cheng L. Tubulocystic carcinoma of the kidney. J Urol 2011;185:2348-9.

23. Bhullar JS, Varshney N, Bhullar AK, et al. A new type of renal cancer-tubulocystic carcinoma of the Kidney: A review of the literature. Int J Surg Pathol 2014;22:297-302.

24. Dhakal HP, McKenney JK, Khor LY, et al. Renal neoplasms with overlapping features of clear cell renal cell carcinoma and clear cell papillary renal cell carcinoma a clinicopathologic study of 37 cases from a single institution. Am J Surg Pathol 2016;40:141-54.

25. Williamson SR, Eble JN, Cheng L, et al. Clear cell papillary renal cell carcinoma: Differential diagnosis and extended immunohistochemical profile. Mod Pathol 2013;26:697-708.

26. Williamson SR, Zhang S, Eble JN, et al. Clear cell papillary renal cell carcinoma-like tumors in patients with von hippel-lindau disease are unrelated to sporadic clear cell papillary renal cell carcinoma. Am J Surg Pathol 2013;37:1131-9.

27. Akgul M, Janaki N, Paspulati RM, et al. Bilateral acquired cystic kidney associated renal cell carcinoma with sarcomatoid features - A rare entity. Hum Pathol Case 
Reports 2018;12:52-5.

28. Przybycin CG, Harper HL, Reynolds JP, et al. Acquired cystic disease-associated renal cell carcinoma (ACD-RCC): A multiinstitutional study of 40 cases with clinical followup. Am J Surg Pathol 2018;42:1156-65.

29. Kuroda N, Tamura M, Hamaguchi N, et al. Acquired cystic disease-associated renal cell carcinoma with sarcomatoid change and rhabdoid features. Ann Diagn Pathol 2011;15:462-6.

30. Tickoo SK, DePeralta-Venturina MN, Harik LR, et al. Spectrum of epithelial neoplasms in end-stage renal disease: An experience from 66 tumor-bearing kidneys with emphasis on histologic patterns distinct from those in sporadic adult renal neoplasia. Am J Surg Pathol 2006;30:141-53.

31. Amin MB, Gupta R, Ondrej H, et al. Primary thyroid-like follicular carcinoma of the kidney: Report of 6 cases of a histologically distinctive adult renal epithelial neoplasm. Am J Surg Pathol. 2009;33:393-400.

32. Jung SJ, Jae IC, Sun HP, et al. Thyroid follicular carcinoma-like tumor of kidney: A case report with morphologic, immunohistochemical, and genetic analysis. Am J Surg Pathol 2006;30:411-5.

33. Eble JN, Delahunt B. Emerging entities in renal cell neoplasia: thyroid-like follicular renal cell carcinoma and multifocal oncocytoma-like tumours associated with oncocytosis. Pathology 2018;50:24-36.

34. Chen X, Dou FX, Cheng XB, et al. Clinicopathologic characteristics of thyroid-like follicular carcinoma of the kidney: an analysis of five cases and review of literature. Zhonghua bing li xue za zhi 2016;45:687-91.

35. Debelenko LV, Raimondi SC, Daw N, et al. Renal cell carcinoma with novel VCL-ALK fusion: New representative of ALK-associated tumor spectrum. Mod Pathol 2011;24:430-42.

36. Lee C, Park JW, Suh JH, et al. ALK-positive renal cell carcinoma in a large series of consecutively resected Korean renal cell carcinoma patients. Korean J Pathol 2013;47:452-7.

37. Bodokh Y, Ambrosetti D, Kubiniek V, et al. ALK-TPM3 rearrangement in adult renal cell carcinoma: Report of a new case showing loss of chromosome 3 and literature review. Cancer Genet 2018;221:31-7.

38. Wang XT, Fang R, Ye S, et al. Targeted next-generation sequencing revealed distinct clinicopathologic and molecular features of VCL-ALK RCC: A unique case from an older patient without clinical evidence of sickle cell trait. Pathol Res Pract 2019;215:152651.
39. Kusano H, Togashi Y, Akiba J, et al. Two cases of renal cell carcinoma harboring a novel STRN-ALK fusion gene. Am J Surg Pathol 2016;40:761-9.

40. Yu W, Wang Y, Jiang Y, et al. Genetic analysis and clinicopathological features of ALK-rearranged renal cell carcinoma in a large series of resected Chinese renal cell carcinoma patients and literature review. Histopathology 2017;71:53-62.

41. Smith NE, Deyrup AT, Mariño-Enriquez A, et al. VCLALK renal cell carcinoma in children with sickle-cell trait: The eighth sickle-cell nephropathy? Am J Surg Pathol 2014;38:858-63.

42. Thorner PS, Shago M, Marrano P, et al. TFE3-positive renal cell carcinomas are not always Xp11 translocation carcinomas: Report of a case with a TPM3-ALK translocation. Pathol Res Pract 2016;212:937-42.

43. Kuroda N, Trpkov K, Gao Y, et al. ALK rearranged renal cell carcinoma (ALK-RCC): a multi-institutional study of twelve cases with identification of novel partner genes CLIP1, KIF5B and KIAA1217. Mod Pathol 2020;33:2564-79.

44. Williamson SR, Gill AJ, Argani P, et al. Report from the International Society of Urological Pathology (ISUP) Consultation Conference on Molecular Pathology of Urogenital Cancers: III: Molecular Pathology of Kidney Cancer. Am J Surg Pathol 2020;44:e47-e65.

45. Pal SK, Bergerot P, Dizman N, et al. Responses to Alectinib in ALK-rearranged Papillary Renal Cell Carcinoma. Eur Urol 2018;74:124-8.

46. Hang JF, Chung HJ, Pan CC. ALK-rearranged renal cell carcinoma with a novel PLEKHA7-ALK translocation and metanephric adenoma-like morphology. Virchows Arch 2020;476:921-9.

47. Rupp NJ, Holger Moch H. ALK-rearranged renal cell carcinoma-different morphological faces of a rare tumor : Editorial to Hang et al. ALK-rearranged renal cell carcinoma with a novel PLEKHA7-ALK translocation and metanephric adenoma-like morphology. Virchows Arch 2020;477:759-60.

48. Canzonieri V, Volpe R, Gloghini A, et al. Mixed renal tumor with carcinomatous and fibroleiomyomatous components, associated with angiomyolipoma in the same kidney. Pathol Res Pract 1993;189:951-6.

49. Kuhn E, De Anda J, Manoni S, et al. Renal cell carcinoma associated with prominent angioleiomyoma-like proliferation: Report of 5 cases and review of the literature. Am J Surg Pathol 2006;30:1372-81.

50. Shannon BA, Cohen RJ, Segal A, et al. Clear cell renal 
cell carcinoma with smooth muscle stroma. Hum Pathol 2009;40:425-9.

51. Iczkowski KA, Shanks JH, Burdge AH, et al. Renal cell carcinoma with clear cells, smooth muscle stroma, and negative for $3 p$ deletion: A variant of renal angiomyoadenomatous tumour? A case report. Histopathology 2013;62:522-4.

52. Williamson SR, Gupta NS, Eble JN, et al. Clear cell renal cell carcinoma with borderline features of clear cell papillary renal cell carcinoma combined morphologic, immunohistochemical, and cytogenetic analysis. Am J Surg Pathol 2015;39:1502-10.

53. Shah RB, Stohr BA, Zheng JT, et al. "Renal Cell Carcinoma with Leiomyomatous Stroma" Harbor Somatic Mutations of TSC1, TSC2, MTOR, and/ or ELOC (TCEB1): Clinicopathologic and Molecular Characterization of 18 Sporadic Tumors Supports a Distinct Entity. Am J Surg Pathol 2020;44:571-81.

54. Hakimi AA, Tickoo SK, Jacobsen A, et al. TCEB1mutated renal cell carcinoma: A distinct genomic and morphological subtype. Mod Pathol 2015;28:845-53.

55. DiNatale RG, Gorelick AN, Makarov V, et al. Putative Drivers of Aggressiveness in TCEB1-mutant Renal Cell Carcinoma: An Emerging Entity with Variable Clinical Course. Eur Urol Focus 2019. [Epub ahead of print].

56. Batavia AA, Schraml P, Moch H. Clear cell renal cell carcinoma with wild-type von Hippel-Lindau gene: a non-existent or new tumour entity? Histopathology 2019;74:60-7.

57. Latif F, Tory K, Gnarra J, et al. Identification of the von Hippel-Lindau disease tumor suppressor gene. Science 1993;260:1317-20.

58. Gnarra JR, Tory K, Weng Y, et al. Mutations of the VHL tumour suppressor gene in renal carcinoma. Nat Genet 1994;7:85-90.

59. Ricketts CJ, De Cubas AA, Fan H, et al. The Cancer Genome Atlas Comprehensive Molecular Characterization of Renal Cell Carcinoma. Cell Rep 2018;23:3698.

60. Dagher J, Kammerer-Jacquet SF, Brunot A, et al. Wildtype VHL Clear Cell Renal Cell Carcinomas Are a Distinct Clinical and Histologic Entity: A 10-Year Followup. Eur Urol Focus 2016;1:284-90.

61. Turajlic S, Xu H, Litchfield K, et al. Tracking Cancer Evolution Reveals Constrained Routes to Metastases: TRACERx Renal. Cell 2018;173:581-594.e12.

62. Kammerer-Jacquet SF, Crouzet L, Brunot A, et al. Independent association of PD-L1 expression with noninactivated VHL clear cell renal cell carcinoma-
A finding with therapeutic potential. Int J Cancer 2017;140:142-8.

63. Cancer Genome Atlas Research Network, Linehan WM, Spellman PT, et al. Comprehensive Molecular Characterization of Papillary Renal-Cell Carcinoma. N Engl J Med 2016;374:135-45.

64. Wong ECL, Di Lena R, Breau RH, et al. Morphologic subtyping as a prognostic predictor for survival in papillary renal cell carcinoma: Type 1 vs. type 2 . Urol Oncol 2019;37:721-6.

65. Paner GP, Amin MB, Alvarado-Cabrero I, et al. A novel tumor grading scheme for chromophobe renal cell carcinoma: Prognostic utility and comparison with fuhrman nuclear grade. Am J Surg Pathol 2010;34:1233-40.

66. Montironi R, Cimadamore A, Ohashi R, et al. Chromophobe Renal Cell Carcinoma Aggressiveness and Immuno-oncology Therapy: How to Distinguish the Good One from the Bad One. Eur Urol Oncol 2020. [Epub ahead of print].

67. Ohashi R, Martignoni G, Hartmann A, et al. Multiinstitutional re-evaluation of prognostic factors in chromophobe renal cell carcinoma: proposal of a novel two-tiered grading scheme. Virchows Arch 2020;476:409-18.

68. Cimadamore A, Cheng L, Ohashi R, et al. Re: Multiinstitutional Re-evaluation of Prognostic Factors in Chromophobe Renal Cell Carcinoma: Proposal of a Novel Two-tiered Grading Scheme. Eur Urol 2020;78:114-6.

69. Ohashi R, Schraml P, Batavia A, et al. Allele Loss and Reduced Expression of CYCLOPS Genes is a Characteristic Feature of Chromophobe Renal Cell Carcinoma. Transl Oncol 2019;12:1131-7.

70. Casuscelli J, Weinhold N, Gundem G, et al. Genomic landscape and evolution of metastatic chromophobe renal cell carcinoma. JCI Insight 2017;2:e92688.

71. Brunelli M, Eble JN, Zhang S, et al. Eosinophilic and classic chromophobe renal cell carcinomas have similar frequent losses of multiple chromosomes from among chromosomes 1, 2, 6, 10, and 17, and this pattern of genetic abnormality is not present in renal oncocytoma. Mod Pathol 2005;18:161-9.

72. Quddus MB, Pratt N, Nabi G. Chromosomal aberrations in renal cell carcinoma: An overview with implications for clinical practice. Urol Ann 2019;11:6-14.

73. Sperga M, Martinek P, Vanecek T, et al. Chromophobe renal cell carcinoma-chromosomal aberration variability and its relation to Paner grading system: An array $\mathrm{CGH}$ and FISH analysis of 37 cases. Virchows Arch 
2013;463:563-73.

74. Tan MH, Wong CF, Tan HL, et al. Genomic expression and single-nucleotide polymorphism profiling discriminates chromophobe renal cell carcinoma and oncocytoma. BMC Cancer 2010;10:196.

75. Ohashi R, Angori S, Batavia AA, et al. Loss of CDKN1A mRNA and protein expression are independent predictors of poor outcome in chromophobe renal cell carcinoma patients. Cancers (Basel) 2020;12:465.

76. Delongchamps NB, Galmiche L, Eiss D, et al. Hybrid tumour "oncocytoma-chromophobe renal cell carcinoma" of the kidney: A report of seven sporadic cases. BJU Int 2009; 103:1381-4.

77. Petersson F, Gatalica Z, Grossmann P, et al. Sporadic hybrid oncocytic/chromophobe tumor of the kidney: A clinicopathologic, histomorphologic, immunohistochemical, ultrastructural, and molecular cytogenetic study of 14 cases. Virchows Arch 2010;456:355-65.

78. He H, Trpkov K, Martinek P, et al. "High-grade oncocytic renal tumor": morphologic, immunohistochemical, and molecular genetic study of 14 cases. Virchows Arch 2018;473:725-38.

79. Chen YB, Mirsadraei L, Jayakumaran G, et al. Somatic mutations of TSC2 or MTOR characterize a morphologically distinct subset of sporadic renal cell carcinoma with eosinophilic and vacuolated cytoplasm. Am J Surg Pathol 2019;43:121-31.

80. Trpkov K, Bonert M, Gao Y, et al. High-grade oncocytic tumour (HOT) of kidney in a patient with tuberous sclerosis complex. Histopathology 2019;75:440-2.

81. Trpkov K, Williamson SR, Gao Y, et al. Lowgrade oncocytic tumour of kidney (CD117-negative, cytokeratin 7-positive): a distinct entity? Histopathology 2019;75:174-84.

82. Davis CF, Ricketts CJ, Wang M, et al. The somatic genomic landscape of chromophobe renal cell carcinoma. Cancer Cell 2014;26:319-30.

83. Ohashi R, Schraml P, Angori S, et al. Classic chromophobe renal cell carcinoma incur a larger number of chromosomal losses than seen in the eosinophilic subtype. Cancers (Basel) 2019;11:1492.

84. Argani P, Ladanyi M. The evolving story of renal translocation carcinomas. Am J Clin Pathol 2006;126:332-4.

85. Argani P, Olgac S, Tickoo SK, et al. Xp11 Translocation renal cell carcinoma in adults: Expanded clinical, pathologic, and genetic spectrum. Am J Surg Pathol
2007;31:1149-60.

86. Meloni AM, Dobbs RM, Edson Pontes J, et al. Translocation $(\mathrm{X} ; 1)$ in papillary renal cell carcinoma a new cytogenetic subtype. Cancer Genet Cytogenet 1993;65:1-6.

87. Gupta S, Johnson SH, Vasmatzis G, et al. TFEB-VEGFA (6p21.1) co-amplified renal cell carcinoma: A distinct entity with potential implications for clinical management. Mod Pathol 2017;30:998-1012.

88. Wyvekens N, Rechsteiner M, Fritz C, et al. Histological and molecular characterization of TFEB-rearranged renal cell carcinomas. Virchows Arch 2019;474:625-31.

89. Ren Q, Wang L, Al-Ahmadie HA, et al. Distinct Genomic Copy Number Alterations Distinguish Mucinous Tubular and Spindle Cell Carcinoma of the Kidney from Papillary Renal Cell Carcinoma with Overlapping Histologic Features. Am J Surg Pathol 2018;42:767-77.

90. Peckova K, Martinek P, Sperga M, et al. Mucinous spindle and tubular renal cell carcinoma: Analysis of chromosomal aberration pattern of low-grade, high-grade, and overlapping morphologic variant with papillary renal cell carcinoma. Ann Diagn Pathol 2015;19:226-31.

91. Wang L, Zhang Y, Chen YB, et al. VSTM2A Overexpression Is a Sensitive and Specific Biomarker for Mucinous Tubular and Spindle Cell Carcinoma (MTSCC) of the Kidney. Am J Surg Pathol 2018;42:1571-84.

92. Mehra R, Vats P, Cieslik M, et al. Biallelic alteration and dysregulation of the hippo pathway in mucinous tubular and spindle cell carcinoma of the kidney. Cancer Discov 2016;6:1258-66.

93. Dhillon J, Amin MB, Selbs E, et al. Mucinous tubular and spindle cell carcinoma of the kidney with sarcomatoid change. Am J Surg Pathol 2009;33:44-9.

94. Ohe C, Smith SC, Sirohi D, Divatia M, et al. Reappraisal of Morphologic Differences between Renal Medullary Carcinoma, Collecting Duct Carcinoma, and Fumarate Hydratase-deficient Renal Cell Carcinoma. Am J Surg Pathol 2018;42:279-92.

95. Gupta R, Billis A, Shah RB, et al. Carcinoma of the collecting ducts of bellini and renal medullary carcinoma: Clinicopathologic analysis of 52 cases of rare aggressive subtypes of renal cell carcinoma with a focus on their interrelationship. Am J Surg Pathol 2012;36:1265-78.

96. Davis CJ, Mostofi FK, Sesterhenn IA. Renal medullary carcinoma: The seventh sickle cell nephropathy. Am J Surg Pathol 1995;19:1-11.

97. Swartz MA, Karth J, Schneider DT, et al. Renal medullary carcinoma: Clinical, pathologic, immunohistochemical, 
and genetic analysis with pathogenetic implications. Urology 2002;60:1083-9.

98. Trpkov K, Hes O, Bonert M, et al. Eosinophilic, solid, and cystic renal cell carcinoma. Am J Surg Pathol 2016;40:60-71.

99. Trpkov K, Abou-Ouf H, Hes O, et al. Eosinophilic Solid and Cystic Renal Cell Carcinoma (ESC RCC): Further Morphologic and Molecular Characterization of ESC RCC as a Distinct Entity. Am J Surg Pathol 2017;41:1299-308.

100.Guo J, Tretiakova MS, Troxell ML, et al. Tuberous sclerosis-associated renal cell carcinoma: A clinicopathologic study of 57 separate carcinomas in 18 patients. Am J Surg Pathol 2014;38:1457-67.

101.McKenney JK, Przybycin CG, Trpkov K, et al. Eosinophilic solid and cystic renal cell carcinomas have metastatic potential. Histopathology 2018;72:1066-7.

102. Tretiakova MS. Eosinophilic solid and cystic renal cell carcinoma mimicking epithelioid angiomyolipoma: series of 4 primary tumors and 2 metastases. Hum Pathol 2018;80:65-75.

103. Palsgrove DN, Li Y, Pratilas CA, et al. Eosinophilic solid and cystic (ESC) renal cell carcinomas harbor tsc mutations: Molecular analysis supports an expanding clinicopathologic spectrum. Am J Surg Pathol 2018;42:1166-81.

104.Mehra R, Vats P, Cao X, et al. Somatic Bi-allelic Loss of TSC Genes in Eosinophilic Solid and Cystic Renal Cell Carcinoma. Eur Urol 2018;74:483-6.

105.Petersson F, Bulimbasic S, Hes O, et al. Biphasic alveolosquamoid renal carcinoma: A histomorphological, immunohistochemical, molecular genetic, and

Cite this article as: Cimadamore A, Cheng L, Scarpelli M, Massari F, Mollica V, Santoni M, Lopez-Beltran A, Montironi R, Moch H. Towards a new WHO classification of renal cell tumor: what the clinician needs to know-a narrative review. Transl Androl Urol 2021;10(3):1506-1520. doi: 10.21037/tau-201150 ultrastructural study of a distinctive morphologic variant of renal cell carcinoma. Ann Diagn Pathol 2012;16:459-69.

106. Hes O, Mundo EC, Peckova K, et al. Biphasic squamoid alveolar renal cell carcinoma: A distinctive subtype of papillary renal cell carcinoma? Am J Surg Pathol 2016;40:664-75.

107. Ulamec M, Skenderi F, Trpkov K, et al. Solid papillary renal cell carcinoma: clinicopathologic, morphologic, and immunohistochemical analysis of 10 cases and review of the literature. Ann Diagn Pathol 2016;23:51-7.

108. Chartier S, Méjean A, Richard S, et al. Biphasic Squamoid Alveolar Renal Cell Carcinoma: 2 Cases in a Family Supporting a Continuous Spectrum with Papillary Type i Renal Cell Carcinoma. Am J Surg Pathol 2017;41:1011-2.

109. Troxell ML, Higgins JP. Renal cell carcinoma in kidney allografts: histologic types, including biphasic papillary carcinoma. Hum Pathol 2016;57:28-36.

110. Trpkov K, Athanazio D, Magi-Galluzzi C, et al. Biphasic papillary renal cell carcinoma is a rare morphological variant with frequent multifocality: a study of 28 cases. Histopathology 2018;72:777-85.

111.Al-Obaidy KI, Eble JN, Cheng L, et al. Papillary Renal Neoplasm with Reverse Polarity: A Morphologic, Immunohistochemical, and Molecular Study. Am J Surg Pathol 2019;43:1099-111.

112. Kim SS, Cho YM, Kim GH, et al. Recurrent KRAS mutations identified in papillary renal neoplasm with reverse polarity - a comparative study with papillary renal cell carcinoma. Mod Pathol 2020;33:690-9.

113.Al-Obaidy KI, Eble JN, Nassiri M, et al. Recurrent KRAS mutations in papillary renal neoplasm with reverse polarity. Mod Pathol 2020;33:1157-64. 